\title{
Difference influence of rubbing and soaking tooth extraction instruments in $70 \%$ alcohol on total oral bacterial colonisation on clinical students at the Department of Oral Surgery and Maxilofacial March- May 2018
}

\author{
Ahyar Riza, ${ }^{*}$ Hendry Rusdy, Isnandar, Evelin N. Sari
}

\section{Abstract}

Objective: To compare the effect of rubbing and soaking tooth extraction instrument in $70 \%$ alcohol on total oral bacterial colonisation at the Department of Oral Surgery, Faculty of Dentistry, Universitas Sumatera Utara.

Material and Methods: This is an experimental research with a post-test only approach. The sampling technique used is Purposive Sampling. In this study, sample were divided into 2 groups consisting of 18 extraction instruments which are lower molar forceps rubbed with $70 \%$ alcohol and soaked in $70 \%$ alcohol. Each instrument were pre-cleaned using brush, water and soap prior disinfection process.

Results: The results were statistically analyzed using Mann-Whitney Test. The result showed no significant difference to the total bacteria count on rubbing and soaking using $70 \%$ alcohol.

Conclusion: Soaking in $70 \%$ alcohol method showed more effective because it overally kills bacteria.
Department of Oral and Maxillofacial Surgery, Faculty of Dentistry, Universitas Sumatera Utara, Medan, Indonesia
*Correspondence to: Ahyar Riza, Department of Oral and Maxillofacial Surgery, Faculty of Dentistry, Universitas Sumatera Utara, Medan, Indonesia

ahyar.riza@usu.ac.id

Received: 20 September 2018 Revised: 26 September 2018 Accepted: 19 July 2019 Available Online: 1 August 2020

Keyword: Disinfection, Forceps, 70\% alcohol

Cite this Article: Riza A, Rusdy H, Isnandar, Sari EN. 2020. Difference influence of rubbing and soaking tooth extraction instruments in $70 \%$ alcohol on total oral bacterial colonisation on clinical students at the Department of Oral Surgery and Maxilofacial March-May 2018. Journal of Dentomaxillofacial Science 5(2): 74-76. D0I: 10.15562/jdmfs.v5i2.815

\section{Introduction}

Infection has been known as a real threat in the dental field. Tooth extraction is one form of dental treatment which has a high risk of transmission of infection. Infection can be directly transmitted through oral fluids, blood, contaminated instruments or respiratory. ${ }^{1,2}$ Disinfection is a way to control infection by reducing the microbial load to a level that makes an object safe to use. Disinfection using chemicals material can kill all bacteria and fungi and some viruses however not spores. ${ }^{3}$

Disinfectant are divided into three groups, namely high level disinfectant such as glutaraldehyde, intermediate level disinfectant such as alcohol and low level disinfectant such as chlorine. Alcohol $70 \%$ is classified as an intermediate level disinfectant, where it can destroy vegetative bacteria, some fungi and viruses but not spores. Alcohol reacts by denaturing proteins and dissolving fat, as a result cell membranes are damaged and enzymes activated by alcohol., ${ }^{4,5}$ Alcohol is bactericidal against vegetative cells, tuberculocidal, but not effective against hydrophilic viruses. ${ }^{6}$

Some researchers explain about disinfection techniques using 70\% alcohol solution. Rubbing and rinsing with $70 \%$ alcohol can reduce the number of bacteria in the contra angle high speed where staphylococcus aureus and pseudomonas aeruginosa were found in contra angle high speed used. ${ }^{7}$ Another study where the application of rubbing and soaking with $70 \%$ alcohol for 2 minutes gave the most optimal results in reducing germ count and giving negative results on the identification of staphylococcus sp. and streptococcus sp. on dental instrument. ${ }^{4}$

From the background described, researcher are interested in examining the difference of rubbing and soaking tooth extraction instruments in alcohol $70 \%$ on total oral bacterial colonisation on clinical students at the Department of Oral Surgery and Maxilofacial March-May 2018.

\section{Material and Methods}

This is an experimental study with post test only control group design approach. Sampling method used in this study is purposive sampling and used lower molar extraction forceps in Department of Oral and Maxillofacial Surgery, Faculty of Dentistry, University Sumatera Utara as sample. In this study, sample were divided into 2 groups consisting of 18 extraction instruments which are lower molar forceps rubbed with $70 \%$ alcohol and soaked in $70 \%$ alcohol. 
Used lower molar extraction forceps were first cleaned with brush, water and soap to eliminate visible blood and saliva on the forceps before disinfection. For rubbing samples, forceps are rubbed with cotton that has been soaked in $70 \%$ alcohol. For soaking samples, forceps are put in a container containing $250 \mathrm{ml}$ of $70 \%$ alcohol for 2 minutes. Forceps were then removed from disinfectant and dried with sterile gauze and the beak of forceps were afterwards immersed in $50 \mathrm{ml}$ of saline for 5 minutes and the container was closed tightly and sent to the microbiology laboratory for bacterial cultivation and colony bacteria count.

The sample solution were then processed through serial dilution $\left(10^{-3}\right)$ and cultivated on plate

Table 1 Number of bacterial colonies after disinfection

\begin{tabular}{lcc}
\hline & \multicolumn{2}{c}{ Number of bacterial colonies (CFU / ml) } \\
\cline { 2 - 3 } No & Rubbing & Soaking \\
\hline 1 & 0 & 0 \\
2 & 0 & 0 \\
3 & 0 & 0 \\
4 & 0 & 0 \\
5 & TNTC & 0 \\
6 & 0 & 0 \\
7 & 0 & 0 \\
8 & 0 & 0 \\
9 & 0 & 0 \\
10 & 0 & 0 \\
11 & 0 & 0 \\
12 & 0 & 0 \\
13 & 0 & 0 \\
14 & 0 & 0 \\
15 & 67 & 0 \\
16 & 0 & 0 \\
17 & 0 & 0 \\
18 & 147 & 0 \\
\hline
\end{tabular}

Table 2 The average number of bacterial colonies

\begin{tabular}{lcc}
\hline Group & Total sample & $\begin{array}{c}\text { Mean and } \\
\text { Standard Deviation (CFU / mL) }\end{array}$ \\
\hline Rubbing & 17 & $12.588 \pm 38.246$ \\
Soaking & 18 & $0.000 \pm 0.000$ \\
\hline
\end{tabular}

count agar and incubated for 24 hours. The number of bacterial colonies formed on the plate count agar then counted using Bacteria Colony Counter. From the bacteria colonized on plate count agar 1 ose was taken to make pure culture of the colony on nutrient agar and incubated for 24 hours. Pure culture was used to observe gram type of the bacteria. Data processing was done by computerized analysis using Mann-Whitney test.

\section{Results}

The results showed that there were differences in the number of bacterial colonization in the $70 \%$ alcohol rubbing group and 70\% soaking in alcohol group. In the rubbing group there were still a number of bacterial colonizations table 1 .

Based on the average test results indicated the number of bacterial colonies in the rubbing group was 12.5882 with a standard deviation of 38.24601 . The average number of bacterial colonies in the soaking group was 0,000 with a standard deviation of 0.000 . These results indicate there are differences in the number of bacterial colonies between rubbing and soaking table 2 .

Shapiro-Wilk test was used to test data normality. The results show that the data is not normally distributed where $\mathrm{p}$ value $=0.000<0.05$. The MannWhitney test was conducted to determine whether there are significant differences between rubbing with $70 \%$ alcohol and soaking in $70 \%$ alcohol. The results obtained $\mathrm{p}$ value $=0.140>0.05$. These results showed that there were no significant differences in the number of bacterial colonies between rubbing and soaking group table 3.

Based on the results and data analysis, it can be concluded that there is no significant difference between of rubbing and soaking the tooth extraction instrument in $70 \%$ alcohol on the number of oral bacterial colonization. Beside the number of bacterial colonies, this study also observed the gram type of bacteria remains in the sample and as the result all of them are gram negative bacteria.

\section{Discussion}

The ability of disinfectant to kill bacteria is influenced by its concentration, time, temperature, and environmental conditions. Alcohol kills bacteria in two ways, protein denaturation and fat membrane

Table 3 The results of the normality and significant test of both group

\begin{tabular}{lccc}
\hline Group & Average and Standard Deviation (CFU / mL) & P-value Normality & P-value (MannWhitney) \\
\hline Rubbing & $12.588 \pm 38.246$ & 0.000 & 0.140 \\
Soaking & $0.000 \pm 0.000$ & 0.000 & \\
\hline
\end{tabular}


dissolution. Alcohol effectively reacts to bacteria, fungi and viruses quickly at optimal concentrations of $60 \%-90 \%$ in water. Alcohol $70 \%$ is used because in the protein mutation alcohol works effectively if there is water, where the water is used as a denatured protein solvent. Alcohol with very high concentrations will only be able to denaturate proteins outside bacterial cells. ${ }^{4,8}$ Vegetative bacteria will die when exposed to $70 \%$ alcohol because this concentration is the most optimal in killing microbes.

The effectiveness of alcohol is very much influenced by protein, such as found in blood and saliva. Instruments surface that will be disinfected by $70 \%$ alcohol should be cleaned firstly from debris, saliva and blood therefore it could adhere well to the surface. ${ }^{7}$ The results showed that there were still a number of bacterial colonization in the rubbing group, where as in the soaking group there was no bacterial colonization. This could be caused by too short contact between the alcohol and the disinfected instrument, consequently causing the alcohol to work not optimally hence the bacteria did not die overall. Disinfecting an instrument using $70 \%$ alcohol should be done by soaking the instrument for two minutes or at least one minute of exposure to alcohol. ${ }^{5,8}$

The results of the study also showed the value of TNTC (Too Numerous To Count) in the rubbing group. This could happen due to the dilution which was carried out three times has not been able to separate the dense and abundant bacterial colonization therefore it cannot be calculated. The purpose of dilution is to reduce the number of microbes suspended in the liquid. Determining the amount of dilution depends on the estimated number of microbes in the sample and the type of sample. For liquid sample, $10^{-1}-10^{-6}$ dilutions are indicated. ${ }^{9-11}$

In this study dilution was carried out three times starting from $10^{-1}, 10^{-2}$ until $10^{-3}$ then counting the number of bacterial colonization in every sample. Another factor that influences the the TNTC value are bacterial contamination during research that increase the number of bacterial colonization. In this study, observation of the gram type bacteria is also done to see bacterial gram type. After the observation of 3 contaminated samples, stained red bacteria were found which is gram negative bacteria.

\section{Conclusion}

There was no significant difference in effect between $70 \%$ alcohol rubbing and soaking in $70 \%$ alcohol to the number of oral bacterial colonization. However, soaking tooth extraction instruments in $70 \%$ alcohol more effective as it can kill the total amount of bacterial colonization. The number of colonization of bacteria found is gram negative bacteria.

\section{Acknowledgment}

I would like to thank all the Lecturer Department of Oral and Maxillofacial Surgery, Ahyar Riza, Hendry Rusdy and Isnandar for guiding and helping me until the completion of this article.

\section{Conflict of Interest}

The authors report no conflict of interest.

\section{References}

1. Suleh MM, Wowor VNS, Mintjelungan CN. Prevention and control of cross infection in the extraction of teeth at the Dental and Oral Hospital of PSPDG FK UNSRAT. J e-GIGI 2015;3: 588. (In Indonesia)

2. Reddy RV, Tanveer K, Sharma KD, et al. Evaluation of effectiveness of chemical disinfectants in reducing bacterial growth on ortodontic instruments. The J Contemp Dent Pract 2013;14: 1039.

3. Pankhurst CL, Coulter WA. Basic guide to infection prevention and control in dentistry. New Delhi: Aptara Inc; 2009. p. 1, 16-25, 93-95.

4. Susatyo JH. The difference in alcohol basting and immersion $70 \%$ in decreasing the number of germ count on dental instruments. J Vokasi Kesehatan 2016;2: 364-368. (In Indonesia)

5. Rutala WA, Weber DJ. Disinfection and Sterilization: An overview. Am J Infect Control 2013;41: S3.

6. Muzhidah, Sukartini T, Sunarno A. The effectiveness of the combination of $0.5 \%$ chlorine and $70 \%$ alcohol on the growth of germs. J Ners 2009;4: 19-21. (In Indonesia)

7. Mulyanti S. Effect of $70 \%$ alcohol swabbing and flushing technique on high speed contra angle toward bacterial count and identification of pathogens. Padjajaran J Dentistry 2009;21: 71.

8. Keen JN, Austin M, Huang L, et al. Efficacy of soaking in $70 \%$ isopropyl alcohol on aerobic bacterial decontamination of surgical instruments and glove for serial mouse laparotomies. J Am Assoc for Lab Anim Sci 2010;49: 832.

9. Yunita M, Hendrawan Y, Yulianingsih R. Microbiological quantitative analysis of Garuda Indonesia aerofood ACS based on Total Plate Count (TPC) with the pour plate method. J Keteknikan Tropis dan Biosistem 2016;3: 237, 241-242. (In Indonesia)

10. Thomas P, Sekhar CA, Upreti R, et al. Optimization of single plate-serial dilution spotting (SP-SDS) with sample anchoring as an assured method for bacterial and yeast cfu enumeration and single colony isolation from diverse samples. Biotechnol Reports J 2015;8: 48-49.

11. Riza A, Oes A, Rusdy H, et al. Comparison of the effectivity of handrubbing and handwashing on the number of bacterial colonization on clinical students at the Department of Oral and Maxillofacial Surgery, Faculty of Dentistry, Universitas Sumatera Utara March-May 2018. J Dentomaxillofac Sci 2019;4: 105-108.

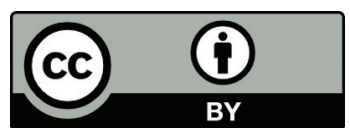

This work is licensed under a Creative Commons Attribution 